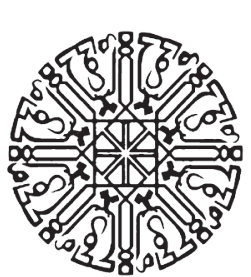

\title{
The Concept of Adultery Post-Revision of The Penal Code
}

\author{
M. Junaidi, S.H., M.Ag. ${ }^{a}$ \\ Resky Gustiandi Candra Imansyah ${ }^{b}$ \\ aLecturer of Law, Universitas Muhammadiyah Surakarta, Surakarta, Indonesia. \\ bStudent of Law, Universitas Muhammadiyah Surakarta, Surakarta, Indonesia. \\ mj122@ums.ac.id \\ reskygustiandi@gmail.com
}

\begin{abstract}
Zina is an act that is prohibited by religion as well as by the state. Adultery is arranged in two rules; in Indonesia it is regulated in the Criminal Code called KUHP. For the case of adultery, it uses offense complaint, which means that it will only be processed criminal law if there is one spouse who reported this legal event. While in Islam, zina's actions are regulated in the Qur'an and Hadith. The problems appeared when the article that regulates zina in the existing criminal code law will be revised its offense from the offense complaint becomes a general offense. This research is under normative research. The type of data in this study is secondary data which were collected by the study method library. The data collected were analyzed by qualitative descriptive method. The result shows that in the Islamic context of adultery, the reporting and proofing process requires only 4 witnesses and it must be seen by firsthand. Whereas in the draft amendment of the criminal law, the adultery will be regulated by general offense resulting in the proof that should be studied not only from the sociological aspect but also the theological aspect
\end{abstract}

Keywords: Zina, Islamic Law, Criminal Law

\section{INTRODUCTION}

Referring to the provisions contained in the 1945 Constitution, Article 1 paragraph (3), stated that: 'Indonesia is a State of Law'. Consequently, all the activities are regulated and run based on the law; including in stipulating penalties for committing adultery by its citizens must also be based on the law. This issue also regulated in the Criminal Code Article 
1 paragraph (1) which is related to Nullum Dilictum Noela Poena Sine Praevia Legi Poenali (D. Shacffmeister 2011). This regulation issued as to strengthen the Article 1 paragraph (3) of the 1945 Constitution above.

The basis of criminal law in Indonesia is based on the Criminal Code which is the result of the adoption of the Dutch colonial government when on the colonization era. However, due to the demand for criminal law requirements that must be in line and meet the heterogeneous Indonesian nuance, ever since then, about 46 years ago, it began for the renewal in the criminal law. Academics and practitioners in the field of law continue to contribute their thoughts in renewing the penal law. Comprehensive criminal law reforms in which this regulates the balance between the public interest and the interests of the state with the interests of the individual, the protection of the perpetrator of the crime and the victim of the crime, the elements of deed and the attitude of the mind, legal certainty and justice, written law and law living in society, national values and universal values, and human rights and basic human rights. Those all become things that must be realized as soon as possible. (Nasional 2015).

In Indonesia, the country has set the law of adultery in the Criminal Code in Chapter XIV, Article 284 paragraph (1), (2) and (3). It is also regulated about the offense in paragraph (2) of the Article named 'complaint offense'. Also in Islamic law, it is also regulated about adultery but more specifically including the offense that is complaint, this all also with the condition of 4 witnesses that must see firsthand of the adultery. The problems arising when the Draft Law (Bill) of the Criminal Code about adultery will be converted into a general offense, it will be very contrary to what has been set by Islam namely complaint delik with 4 witnesses as a condition of validity of the complaints. When adultery becomes a common offense, it will be very vulnerable to give a big gap for the slander.

Islamic law that the norm comes from God Almighty whose the contents are about the prohibitions, orders, and suggestions that benefit for human beings. Allah Almighty states His law as to maintain the benefit of human, as well as to avoid mafsadat, both in the world and in the hereafter (M. Huda 2006). Therefore Islam laid down the Criminal Acts of Adultery as ordinary offense or public offense and not as offense complaint: it is mentioned that Delik Aduan is a criminal offense that can only be prosecuted if there is a complaint from the person in disadvantage.

As in the Criminal Code, the offense of the absolute complaint is a delict which, by its nature, under any circumstances can only be prosecuted on the basis of a complaint. The grievance action here is necessary to demand the event so that everything concerned with it must be prosecuted. (Rambe, et al. 2016). Because the aim of prohibiting adultery is 
not just for the sake of keeping marriage and descendants, but the prohibition of adultery is also to keep the mind, keep the soul, prevent various diseases and prevent the $a d z a b$ of Allah SWT.

Zina according to Islamic law is not only a great sin, but also cause negative to physical health, namely the emergence of venereal disease. (H. A. Muslich, Hukum Pidana Islam 2005). In addition, adultery is also contrary to the moral, the nature of glory, virtue and nobility, destroying the structure of community and family life, disrupt descendent, sever the relationship of husband and wife and damage the child's education. (Jaziry 1993) In other words, the bad effects of adultery include the moral, religious, physical, social, and family fields. (Jaziry 1993)

With the renewal interesting also what has been stated by Prof. Oemar Senoadji around the crimes against this decency that in filling and directing the moral offenses, religious elements should play their part. It is good to note his statements around the view of the mere relation between law and morals, as if the influence of the religious element on the law is not addressed, especially in the crimes of decency (Jaziry 1993). In line with the opinion expressed by prof. Oemar Senoadji above, then the norm of decency should be guided by religion, including in the formulation of the offense in the 'RUU KUHP' needs to be based on religion, so the resulting formula will be in line with all aspects of life that is also based on religion.

\section{THEORETICAL BACKGROUND}

Zina means fahisyah, which is a vile act. While zina according to the term is a sexual relationship between a man with a woman who is not bound to each other in a marital relationship. (A. Doi 1991) Understanding adultery in the western world is defined as intercourse committed in which one of the perpetrators or both perpetrators are bound marriage with others (S. Huda 2015). Meanwhile, according to Islam, zina is any sexual relationship outside of marriage and threatened him with punishment, whether the perpetrator has been married or not, done with likes or not. H.A. Djazuli explains that adultery is any sexual intercourse that is forbidden, whether committed by people who have married and who have not married as long as he belongs to mukallaf, although it is done willingly (Ishak 2012). According to the fuqaha (jurist of Islamic law) adultery is to have sexual intercourse in the sense of entering the penis (male sex) into the vagina of women that declared haram, not because syubhat and on the basis of lust. Zina is defined as a male sexual relationship with a woman who is not a legal husband (outside marriage), (Abidin 1962). The word 'zina"'’applies to a married or not (A. R. Doi 1996). 
There is some understanding of adultery according to the scholars who will add insight about adultery as explained below:

a. Zina according to figh is intercourse between men and women without any legitimate marriage bonds, which include male genitalia into the genitals of women, at least to the limit of hasyafah (the head of the penis). (Mujieb 2002)

b. According to Abdul Halim Hasan, adultery means a man inserting his genitals into a woman's genitals, with no marriage and no occurrence with the subhat. (Hasan 2006)

c. According to Ibn Rushd the definition of adultery is intercourse is done not because of a legal marriage / semi-marriage and not because of the ownership of the servant sahaya.

d. According to Hamka, adultery is all sexual intercourse outside of marriage, and in other juzu he defines adultery as any intercourse that is not legalized by marriage, or unlawful marriage (Hamka 1983).

e. According to the Encyclopedia of Islamic Criminal Law, the definition of adultery according to some madhhab, although different in the same way but the same intention is the intercourse between men and women conducted by mukallaf that is not bound by legitimate marriage. (Audah 1983)

f. According to the Great Indonesian Dictionary, the adultery word contains the following meanings: 'The act of intercourse between men and women who are not bound by marital relationships (marriage)'; intercourse of a woman who is not his wife or a woman who is married to a man who is not her husband. (Gunadi dan Efendi 2014)

Thought, it can be understood adultery is the act of intercourse between men and women who are not a legitimate marriage couples, if according to the concepts applied by the Dutch, then someone can be said to be adultery when one or both there is a legal marriage bond with others, whereas if according to the concept of Islam, is categorized as adultery when between male and female sex occurs, whether one is married or still unmarried. So the scope of the law is wider if using the concept of Islam.

Below is the explanation which depicted in fishbone flow chart:

al-aḥ̂ām vol. 3, Nomor 1, 2018 




Image 1. Fishbone Cause, Effect and Solution

The main purpose of criminal law is to protect the interests of society as a collectivity of the actions that threaten or even harm it either comes from individuals or groups of people (an organization), (Gunadi dan Efendi 2014). While the court theory, there are 3 namely retributive theories; relative theory and mixed theory. The retributive theory is how the purpose of punishment is to give a reply to the actions of the perpetrators of both crime and offense. While the relative theory that is about the purpose of punishment is to provide benefits for changes in behavior after being sentenced to criminal. Meanwhile mixed theory is a mixture between the two that is how on the one hand gives vengeance to the perpetrator of his actions, and on the other hand provides the benefit to change his behavior.

\section{RESEARCH METHOD}

The research approach used in this paper is a normative research. The type of research is under descriptive qualitative. The type of data used is a secondary data. This research is also referred to as literature research or document studies, as this research is conducted or directed only on written regulations or other legal and written data materials. The data used consist of primary, secondary, and tertiary data. It is also stated to be a library research or document study because this research is mostly done on secondary data in libraries and journals and trusted information media. These secondary data can be private and public. In normative legal research, secondary data as information sources / materials can be primary legal materials, such as Laws and Regulations related to Adultery, in KUHP, and Islamic Law; secondary law materials, in the form of expert opinions, scientific papers, 
journals and the results of a study; and tertiary legal materials such as encyclopedias, dictionaries and others (Suratman dan Dillah 2013).

\section{RESULT AND DISCUSSION}

\section{A. Criminal Acts of Adultery in Perspective of Islamic Law}

In connection with Zina, Islamic law has regulated its punishment very specific and different from the concept governed by non-Islamic law. Here is the criminal acts of adultery according to Islam:

\section{Elemental Elements of Adultery}

The actors of adultery, whether muhsan or ghoiru muhsan who has fulfilled the element of adultery offense, will be given a legal sanction in the form of hudud which has been determined in the Qur'an. The elements are as follows:

a. The existence of sexual intercourse between two people of different sex (heterosex), and the absence of similarity or error (syubhat) in sex act (sex act). Sex is thought to be minimal adultery with the setting of hasyafah (shoot) on the farji, though not the ma does not erect (Audah 1983). In addition the perpetrators also know that their sexual intercourse is haram. In the crime of adultery, male and female adulterers are prescribed to have intent or intention to oppose the law. Unlawful intentions are deemed to be fulfilled if the perpetrator knows that he did a sex with a woman that is forbidden to him. Also if the adulteress lets herself and knows that the person who intercourse her is not a lawful for her. (Audah 1983)

b. The perpetrator is a mukallaf. Islam stipulates that any mukallaf may be charged with hudud punishment if proven to commit adultery regardless of whether married or unmarried. (Hartono 2009) .

c. Adultery is the intercourse that committed in a state of conscious without coercion, meaning that the perpetrators have agreed to commit adultery not because of coercion. Sexual intercourse is rape. If one party is forced, then he is not the perpetrator but the victim. In the case of this rape, the perpetrator is still under the law of had, while the victim does not.

d. There is evidence of adultery.

\section{Proof of Adultery Delik}

Proof is one of the series in the judiciary that plays an important role. This is because proof is a process that determines the guilt or innocence of a person. If the evidence submitted in court is inadequate or not in accordance with the requirement, the suspect

al-ạ̣kām Vol. 3, Nomor 1, 2018 
will be released. However, if the evidence submitted is sufficient then the suspect may be found guilty. Therefore the proofing process is an important process in order not to get the guilty person released because of insufficient evidence. Or even innocent people are found guilty.

In the dictionary of law, proof is defined as something that states the truth of an event, real information, witnesses, signs, things that are a sign of evil deeds (Sudarsono 1996). Proof or in Islam which can be called also al-bayyinah, etymologically meaning information, that is everything can be used to explain the truth. In technical terms, means means of evidence in court. Al-bayyinah is defined by the figh scholars according to their etymological understanding. In terminology, it is proving a case by proposing reason and giving the argument up to the convincing limit. (Mahmassan 1998)

The evidence in Islamic law is different from the theories of the system of evidence in general, other than because Islamic law is not a law based on the common law or civil law system, also because the proof system is based on the Qur'an, As-Sunnah, and ar-ra'yu or the reasoning is usually the opinions of jurists or scholars (Ali 2007). In the case of proof, the burden to prove the truth of the charge or lawsuit in Islamic procedural law, laid on the shoulder of the accuser or the hijacker, among the general rules, the proof is to establish something contrary to birth, while the oath is done to defend the original law (reality). The proof of the crime of adultery is done with three types of evidence: (A. W. Muslich 2005)

\section{a. Proof with witness}

In the crime of adultery the minimum number of witnesses is four persons. These four witnesses must see firsthand the incident. They must see the events with their own eyes. This can not only hear the incident from others, because it will cause doubt (syubhat) which can cause hudud, which is the punishment falls. The legal basis of the terms of this witness is An-Nisa verse 15 which is 'and (against) the women who do evil deeds, let there be four witnesses among you (witnessing)'.

b. Recognition

Recognition as evidence of several conditions that must be met, among others:

1. Recognition must be stated four times and in detail so as to eliminate syubhat (doubt).

2. Recognition shall be carried out in detail and explain the nature of the act so as to eliminate the vagueness of such adultery.

3. It should be legitimate or righteous, and it is impossible to arise except from the intelligent and liberal.

4. Recognition shall be stated in court. 


\section{c. Proof with a clue or qarinah}

Qarinah (sign) which is considered as a means of proof is the incidence of pregnancy in women who are not married, or unknown to her husband or the womb born before six months.

\section{The Punishment Of Adultery}

Islamic law is prescribed to preserve the welfare. That benefit can be realized if the five basic elements can be realized and maintained. The five main elements, according to al-Shatibi are religion, soul, descendant, mind and property (Bakri 1996), these five main elements in Islamic legal literature known as Ushul al-Khamsah. One of the five is to keep the offspring of urging for marriage is prohibited the adultery. Zina belongs to the finger whose punishment is hudud, i.e the punishment prescribed by Allah Almighty in al-Qur'an, as well as in al-Hadith.

Zina is any sexual relationship outside of marriage and threatened her with punishment, whether the perpetrator has been married or not, done with likes or not. $(\mathrm{H}$. A. Muslich, Hukum Pidana Islam 2005) Then H.A. Djazuli explains that adultery is any sexual intercourse that is forbidden, whether committed by people who have married and who have not married as long as he belongs to mukallaf, although done willingly. (Djazuli 1997) The act of adultery is an outrageous crime that exceeds the limit, then threatened with punishment, namely the punishment that has been determined by syará, and the rights of God (community rights). (H. A. Muslich, Pengantar dan Asas Hukum Pidana Islam 2006)

There are two kinds of adultery that gets compulsory punishment for the perpetrators, namely: Ghairu Muḥșan and muhsan. Ghoiru muhsan, meaning a zina committed by a person who has never held a legal marriage (Djamali 1996). This means that adulterers who are still single or virgin, i.e those who are not married. For the punishment imposed on the adulterer with the status of ghair muhșan is a hundred times dera, based on Q.S. al-Nūr (24): 2. The execution of punishment should be carried out in front of a crowd, i.e a group of believers, though it is expected to give a deterrent effect and influence the souls of those who have committed adultery and teach the people witnessed the execution of the sentence. Besides being ravaged a hundred times, the adulterers of ghair muhșan were also exiled for a year, relying on Ibn al-Munzir's statement which says: 'In the case of a servant who commits adultery with the daughter of the princess, the Messenger of Allah'. Sworn that he would decide upon him according to the Book of Allah. Then he declared, that the servant should be punished dera as much as a hundred times and exiled for a year.

While Muhșan, is an adultery committed by people who have been balig, intelligent, independent and have been mixed with a legal person with another sex (Djamali 1996). The penalty for the perpetrators of adultery who are muhșan status is stoning. Rajam is the 
death penalty by stoning (Audah 1983). Because the stoning punishment is not clear in the Qur'an, the khawarij deny it. According to them the punishment for adulterer's muhșan as well as ghair muhșan is the same that is suffered.

\section{B. Zina Criminal Act in the Draft Law of the Penal Code}

Barda Nawawi Arief argues for the renewal of the Indonesian Criminal Code: 'The renewal of the penal law in essence implies, an attempt to reorient and reform the penal law in accordance with socio-political, socio-philosophical and socio-central valuescultural society that underlies social policies, criminal policies and enforcement policies in Indonesia'. In line with the above explanation, Sudarto also explained that there are three reasons why we need to renew the Criminal Code, which is political, sociological, and practical (practice in practice). While Jimly Assiddiqie said that the need for the Criminal Code was revised based on political, philosophical, sociological and even practical reasons. (Ishak 2012) Acts of adultery contained in Article 284 of the Criminal Code. This article is an absolute complaint offense (Gunadi dan Efendi 2014). Article Adultery is a criminal act of modesty in the matter of intercourse and entered into a type of crime (Kurniawan 2013). Against criminal acts against decency it still must be equipped with: (Nasional 2015)

a. A formula which will provide the limits and contents of what is meant by violating the decency;

b. Affirming the acts as a criminal act against morality, whether by observing the legislation of other countries, as well as the determination of new crimes unearthed from religious norms relating to decency; and

c. Fixed constructions around the previous criminal offenses that have existed in our legislation by adjusting them to the idea that the law has a strong backing on religious morals. So that the reforms being prepared must take into account the sociological aspects as mentioned above such as human rights, the attitude of the mind and the law who live in society so that the attention is not only juridical course.

\section{Elemental Elements of Adultery}

In the old Criminal Code as well as the renewal version is also regulated concerning acts of decency like adultery. Hence, this becomes the basis for punishing the subject that violates it. Based on Article 284 of the Criminal Code, the following elements can be drawn:

a. Subjects that do that is a man and a woman, then also including men and / or women who participate in the act of decency.

b. Status one or both is married. If both offenders are not bound by a legal marriage, then the Criminal Code cannot entrap it because in article 284 paragraph (1), it is 
mentioned that what can be charged with adultery is done by a married man or married woman. In this context, article 27 of the Civil Code (BW) stipulates that a man should be bound by marriage with only one woman, and a woman with only one man. (S. Huda 2015) Thus providing an opportunity for unmarried men or women to be able to freely commit adultery.

\section{Proof of Adultery Offense}

To be the reason and foundation in determining the punishment for someone who violates the rule of law, then the proof takes a very important role. According to Mohammad Taufik Makarao and Suhasril: (Kurniawan 2013)

'Evidence is a problem that plays an important role in the process of examining the trial. With this proof is determined the fate of the defendant. If the result of evidence with evidence provided by law is not sufficient to prove the defendant's accused, the defendant is released from the sentence. On the contrary, if the defendant's faults can be proven by the evidences mentioned in Article 184 of the Criminal Procedure Code, the defendant must be found guilty. To him shall be punished. Therefore, the judges must be careful, thorough, and mature assessing and considering the problem of proof.

Regarding the way of proof applied by the Criminal Code (Penal Code) is as follows:

a. The offense used is an absolute complaint offense that is a criminal offense that can only be prosecuted if there is a complaint from the person in disadvantage. As in the Criminal Code, the offense of the absolute complaint is a delict which, by its nature, under any circumstances can only be prosecuted on the basis of a complaint. The grievance action here is necessary to demand the event so that everything concerned with it must be prosecuted. (Rambe, et al. 2016)

b. A complaint must be made by the husband or wife of one of the couples committing adultery.

This is different from the Criminal Code Bill that in the design, will be used the method of proof through a general offense that is the consequence if used public offense. According to Tunggal, the expansion of the adultery section has the potential to create persecution and vigilante culture in the community. Therefore, any person who feels has an interest can conduct raids or prosecution of a couple who allegedly doing intercourse somewhere (Erdianto 2018). Furthermore, anyone who knows, will be able to report to law enforcement officers without evidence and legal facts that clearly know about the crime of adultery in the form of adultery. Then also the question whether the bill provides certainty in the element of crime as well as in Islam with the method of proof that requires reporters to see directly the process of intercourse between the two partners and as many as 4 men

al-ạ̣kām Vol. 3, Nomor 1, 2018 
as conditions. So in the determination of this must consider from the religious side not only from the social side.

\section{The Punishment Of Adultery}

The main purpose of criminal law is to protect the interests of society as a collectivity of the actions that threaten or even harm it either comes from individuals or groups of people (an organization), (Gunadi dan Efendi 2014). Thus the punishment in the offense of adultery is an attempt to guard, protect and align the behavior of human acts that initially violate the law in the form of criminal morality becomes law-abiding. Regarding the punishment in the offense of adultery is as follows:

a. The imprisonment imposed by the Criminal Code is a maximum of 9 months. This is certainly very loose for the perpetrators, so it still has the potential for repetition of this kind of crime when it has finished the sentence. In the RUU KUHP in Article 483 paragraph (1) maximum penalty imposed is for 5 years. This is certainly very hopeful for such a reduction in crime because of the length of time.

b. The existence of exceptions in the prosecution that causes do not apply if Article 27 Civil Code.

c. Can be withdrawn during the trial in the trial has not started yet.

Thus, there is a renewal of the Penal Code especially against Article 284 regarding Zina and its offense. Moreover, it will affect the process of proof, if a general offense, then this will facilitate the emergence of slander and public action that could lead to the vigilante itself because the offense is a general offense. So in the renewal must pay attention to the aspect of religion, especially related to decency in Indonesian society who hold tough religious principles, the goal is to make the formula in harmony with the guidance of religion, because morally with the guidance of religion will be organized rather than morality just stand alone following the human desire that sometimes not meet the proportionality of justice.

\section{CONCLUSION}

The actors of adultery, whether muhsan or ghoiru muhsan who has fulfilled the element of adultery offense, will be given a legal sanction in the form of hudud which has been determined in the Qur'an. The element is the existence of sex, the perpetrator is mukallaf. In addition there is evidence of adultery. Proof of adultery is committed with three types of evidence; 1) Verification with witnesses; 2) Recognition; 3) Proof with the guidance or qarinah Then about the punishment offenses adultery, Islamic law is prescribed to maintain the benefit. That benefit can be realized if the five basic elements can be 
realized and maintained. There are two kinds of adultery that gets compulsory punishment for the perpetrators, namely: Ghairu Muhșan and muhsan. Ghoiru muhsan, meaning a zina committed by a person who has never held a legal marriage. This means that adulterers who are still single or virgin, i.e those who are not married

Acts of adultery contained in Article 284 of the Criminal Code. This article is an absolute complaint offense. Article Adultery (overspel) is a criminal act of modesty in the matter of intercourse and entered into a type of crime. In the old Criminal Code as well as the renewal version is also regulated concerning acts of decency like adultery. So this becomes the basis for punishing the subject that violates it. Subjects that do that is a man and a woman, then also including men and / or women who participate in the act of decency. The status of either or both is married to be the reason and the basis for determining the punishment for someone who violates the law, then the proof takes a very important role. The offense that is used is the absolute complaint offense means that the complaint must be made by the husband or the wife of one of the couples committing adultery. The imprisonment imposed by the Criminal Code is maximum for 9 months, whereas in the RUU KUHP in Article 483 paragraph (1) the maximum penalty imposed is for 5 years and can be withdrawn while the examination in the trial has not started yet.

Moreover, in the renewal must pay attention to the aspect of religion, especially related to decency in Indonesian society who hold tough religious principles, the goal is to make the formula in harmony with the guidance of religion, because morally with the guidance of religion will be organized rather than morality just stand alone following the human desire that sometimes not meet the proportionality of justice.

\section{DAFTAR PUSTAKA}

Abidin, Zainal. Hukum Pidana. Jakarta: Prapanca, 1962.

Ali, Zainudin. Hukum Pidana Islam. Jakarta: Sinar Grafika, 2007.

Audah, Abdul Qadir. Ensiklopedi Hulum Pidana Islam. Jakarta: Pustaka Panjimas, 1983.

Bakri, Asafri Jaya. Konsep Maqashid Syariah Menurut Al-Syatibi. Jakarta: Raja Grafindo Persada, 1996.

D. Shacffmeister, N. Keijzer dan Sutorius. Hukum Pidana. Bandung: Penerbit PT. Citra Aditya Bakti, 2011.

Djamali, Abdul. Hukum Pidana Islam. Jakarta: Sinar Grafika, 1996.

Djazuli, H. A. Fiqih Jinayah. Jakarta: Raja Grafindo Persada, 1997.

Doi, A. Rahman I. Hudud dan Kewarisan. Jakarta: PT. Raja Grafindo Persada, 1996.

Doi, Abdurrahman. Tindak Pidana Dalam Syariat Islam. Jakarta: Rineka Cipta, 1991.

al-ạ̣kām Vol. 3, Nomor 1, 2018 
Erdianto, Kristian. Kompas.com. Januari 30, 2018. , https://nasional.kompas.com/ $\mathrm{read} / 2018 / 01 / 30 / 18340811 /$ pasal-zina-di-ruu-kuhp-dikhawatirkan-buatmasyarakat-main-hakim-sendiri (accessed April 26, 2018).

Gunadi, Ismu, and Jonaedi Efendi. Cepat dan Mudah Memahami Hukum Pidana. Jakarta: Penerbit Kencana Prenadamedia Group, 2014.

Hamka. Tafsir Al-Azhar. Jakarta: Pustaka Panjimas, 1983.

Hartono. "SMA Khadijah Surabaya." Pengertian Zina. Maret 2, 2009. http://dirga-smakhadijah-surabaya. blogspot.com (accessed 4 6, 2018).

Hasan, Abdul Halim. Tafsir Al Ahkam. Jakarta: Kencana, 2006.

Huda, Miftahul. Filsafat Hukum Islam Menggali Hakikat, Sumber dan Tujuan Hukum Islam. Ponorogo: STAIN Ponorogo Press, 2006.

Huda, Syamsul. "Zina Dalam Perspektif Hukum Islam dan Kitab Undang-Undang Hukum Pidana." Hunafa: Jurnal Studia Islamika, 2015: 379.

Ishak. "Analisis Hukum Islam Tentang Perbuatan Zina Dalam Pasal 284 Kitab Undang-Undang Hukum Pidana Dalam Pembaharuan Hukum Pidana." Kanun Jurnal IImu Hukum, 2012: 168.

Jaziry, Abdurrahman Al. Kitabul Fiqhi Ala Madzahibil Arba'ah. Bairut: Darul Fikri, 1993.

Kurniawan, Adi. Pembuktian Tindak Pidana Perzinahan Yang Dilakukan Oleh Militer (Studi Terhadap Putusan Pengadilan Militer Tinggi II Jakarta Nomor: 14/K-AD/PMT/-II/ VI/2010). Skripsi , Purwokerto: Fakultas Hukum Universitas Jenderal Soedirman, 2013.

Mahmassan, Sobhi. Filsafat Hukum Dalam Islam. Bandung: PT. Al-Ma'Arif, 1998.

Mujieb, M. Abdul. Kamus Istilah Figh. Jakarta: Pustaka Firdaus, 2002.

Muslich, Ahmad Wardi. Hukum Pidana Islam. Jakarta: Sinar Grafika, 2005.

Muslich, H. Ahmad Wardi. Hukum Pidana Islam. Jakarta: Sinar Grafika, 2005.

-. Pengantar dan Asas Hukum Pidana Islam. Jakarta: Sinar Grafika, 2006.

Nasional, Badan Pembinaan Hukum. Draft Naskah Akademik Rancangan Undang-Undang Tentang Kitab Undang-Undang Hukum Pidana. Jakarta: Kementerian Hukum dan Hak Asasi Manusia Republik Indonesia, 2015.

Rambe, Hendri Nauli, Alvi Syahrin, M. Hasballah Thaib, and Marlina. "Perzinahan Dalam Presfektif Islam Sebagai Alternatif Pembaharuan Hukum Pidana Tentang Perzinahan Di Indonesia." USU Law Journal, Vol.4. No.1, 2016: 77.

Sudarsono. Kamus Hukum. Jakarta: Grafika, 1996.

Suratman, and H. Philips Dillah. Metode Penelitian Hukum. Bandung: CV. Alfabeta, 2013. 
